\title{
Editorial: \\ The »New Monetary Policy« - A Critical Appraisal
}

\author{
Giuseppe Fontana*, Claude Gnos ${ }^{\circ}$ and Achim Truger ${ }^{\diamond}$
}

The "New Monetary Policy" (NMP) is the major stabilisation policy associated with the so-called "New Consensus" (NC) view in macroeconomics. ${ }^{1} \mathrm{NC}$ is the dominant view in modern mainstream economics. Its major tenets are (I) the supply-side determined equilibrium level of unemployment (e.g. NAIRU), and, related to it, (2) the acceptance of the long-run Phillips curve. Within this classical framework, the NC has first explored and then supported a role for short-run effective stabilisation policies, which have usually meant aggregate demand fine-tuning via changes in the short-run nominal interest rate controlled by the central bank. The contributions to this special issue, which contains some of the papers presented at the workshop on Macroeconomics and Macroeconomic Policy organized by the Research Network Alternative Macroeconomic Policies (Germany), the Post Keynesian Economic Study Group (UK), and the Association pour le Développement des Études Keynésiennes (France) on $28^{\text {th }}$ and $29^{\text {th }}$ October 2005 in Berlin, discuss this NC view and its NMP implications from a variety of perspectives and economic traditions.

The first paper titled New Monetary Policy and Keynes is by Philip Arestis (University of Cambridge). The purpose of this paper is to compare the modern approach to monetary policy (i.e. NMP) with some of Keynes's ideas as propounded in an original pamphlet in 1932. Keynes was one of the first economists to suggest the independence of the central bank but, differently from the NMP, he also recognised and defended the long-run real effects of monetary policy. The historical roots of NMP are also explored in the second paper The "New Consensus "View of Monetary Policy: A New Wicksellian Connection? by Giuseppe Fontana (University of Leeds). In this paper the recent developments in the theory and practice of monetary policy are evaluated in terms of two alternative frameworks, namely the quantity-theoretic approach and the Wicksellian "two-interest-rates"approach.

In the third paper Rethinking the Role of Monetary Policy and Wage Bargaining in a World Without the Real Balance Effect, Sebastian Dullien (Financial Times Deutschland) examines the critical role of the real balance effect in supporting the short-run real effects

* University of Leeds.

- University of Burgundy.

- Macroeconomic Policy Institute in the Hans Böckler Foundation, Düsseldorf.

I See, e.g., Clarida et al. (1999), Romer (2000) and the textbook by Carlin/Soskice (2006), and, for a critical appraisal of the NMP, the contributions in Arestis et al. (2005).

(C) INTERVENTION 3 (2), 2006, 243-244 
defended by the NMP. In a world of endogenous money the real balance effect does not have any meaning, and it should be replaced in the NMP model by a sound analysis of the policy effects of different wage bargaining regimes. This suggestion is further explored in Wage Bargaining and Monetary Policy in a Kaleckian Monetary Distribution and Growth Model: Trying to Make Sense of the NAIRU by Eckhard Hein (Macroeconomic Policy Institute in the Hans Böckler Foundation). By using a Kaleckian monetary and distribution model the author explores the real debt effects associated with the NMP, before concluding that wage bargaining co-ordination is a more appropriate tool than monetary policy for controlling inflation. The ineffectiveness of monetary policy is also at the core of the paper A Kaleckian Analysis of Monetary Policy by Malcolm Sawyer (University of Leeds). After briefly setting out the essential features of the Kaleckian macroeconomic approach, Sawyer draws attention to the complex relationship between changes in the short-run nominal interest rate, the inflation rate and the level of economic activity. Finally, Tom Palley (Economics of Democratic and Open Societies) concludes the special issue with a paper titled Currency Unions, the Phillips Curve, and Stabilization Policy: Some Suggestions for Europe. By using a multi-country model with downward nominal rigidity, Palley shows that the formation of a currency union like Euroland worsens the inflation-unemployment tradeoff and calls for general fiscal automatic stabilizers or country-specific policy instruments like asset-based reserve requirements (ABRR) to improve the macroeconomic situation.

\section{References}

Arestis, Philip / Baddeley, Michelle / McCombie, John (eds.): The `New` Monetary Policy: Implications and Relevance, Aldershot: Edward Elgar

Carlin, Wendy/ Soskice, David (2006): Macroeconomics: Imperfections, Institutions and Policies, Oxford: Oxford University Press

Clarida, Richard/Galí, Jordi / Gertler, Mark (1999): The Science of Monetary Policy: A New Keynesian Perspective, in: Journal of Economic Literature, Vol. 37, No. 4, pp. 166I-1707

Romer, David (2000): Keynesian Macroeconomics Without the LM Curve, in: Journal of Economic Perspectives, Vol. I4, No. 2, pp. I49-169 